\title{
FORUM
}

\section{Azadirachtin from the Neem Tree Azadirachta indica: its Action Against Insects}

\author{
A. Jennifer Mordue (Luntz)* and Alasdair J. Nisbet \\ Department of Zoology, University of Aberdeen, Tillydrone Avenue, \\ Aberdeen,AB24 2TZ - Scotland. *Author for correspondence
}

An. Soc. Entomol. Brasil 29(4): 615-632 (2000)

Azadiractina do Nim, Azadirachta indica: sua Ação Contra Insetos

\begin{abstract}
RESUMO - Aárvore do nim há muito tempo é reconhecida por suas propriedades singulares de ação contra insetos e benefício à saúde humana. É plantada na maior parte das áreas tropicais e subtropicais do mundo para sombra, reflorestamento e produção de matéria prima para inseticidas naturais e medicamentos. A azadiractina, complexo tetranortriterpenóide limonóide das sementes é o principal composto responsável pelos efeitos tóxicos aos insetos. Seis conferências internacionais sobre nim e vasta literatura científica relatam esses aspectos. Este artigo revê as propriedades da azadiractina no comportamento e na fisiologia de insetos, incluindo os efeitos na reprodução, redução da alimentação tanto direto quanto a chamada "secundária", redução do crescimento, aumento da mortalidade e ocorrência de ecdises anormais e tardias. Os efeitos fisiológicos são aqui categorizados de duas maneiras: efeitos diretos sobre as células e os tecidos e efeitos indiretos exercidos via o sistema endócrino. $\mathrm{O}$ artigo também descreve o trabalho feito até o momento visando identificar o modo de açao da azadiractina em nível celular e seus efeitos diferentes entre filos animais e sobre organismos não nocivos, o que indica seu sucesso potencial como inseticida seguro.
\end{abstract}

PALAVRAS-CHAVE: Insecta, inseticida botânico, fisiologia de insetos.

ABSTRACT - The neem tree has long been recognized for its unique properties both against insects and in improving human health. It is grown in most tropical and sub-tropical areas of the world for shade, reforestation and for the production of row material for natural insecticides and medicines. Azadirachtin, a complex tetranortriterpenoid limonoid from the neem seeds, is the main component responsible for the toxic effects in insects. Six international conferences on neem and a vast scientific literature report both the antifeedant and physiological effects of neem. This article reviews the behavioral and physiological properties of azadirachtin, including effects on insect reproduction, direct and "secondary" antifeedancy, and the physiological effects measured as growth reduction, increased mortality and abnormal and delayed moults. These effects are here categorized in two ways: direct effects on cells and tissues and indirect effects exerted via the endocrine system. It also describes the work carried out to date to identify the mode of action of azadirachtin at the cellular level. The differential effects between animal phyla and over non-target organisms are discussed and point to its potential success as a safe insecticide.

KEY WORDS: Insecta, botanical insecticide, insect physiology. 


\section{Introduction}

The neem tree (Azadirachta indica A. Juss), from the Meliaceae (mahogany) family, known as margosa or Indian lilac, has long been recognized for its properties both against insects and in improving human health. The neem tree is an attractive broad leaved evergreen which can grow up to $30 \mathrm{~m}$ tall with spreading branches covering some $10 \mathrm{~m}$ across. The flowers and fruits are borne in axillary clusters and when ripe the smooth ellipsoidal drupes are greenish yellow and comprise a sweet pulp enclosing a seed. The seed consist of a shell and 1-3 kernels which contain azadirachtin and its homologues. Both the bark and leaves also contain biologically active molecules but not high levels of azadirachtin which is found mainly in the seed kernels. Here, azadirachtin occurs on amounts of some $4-6 \mathrm{gkg}$ seeds depending upon tree ecotype and local environmental conditions. Mature trees may produce some $2 \mathrm{~kg}$ of seed per year. The tree is now grown in most tropical and sub-tropical areas of the world for shade, for reforestation programmes and in plantations for the production of compound which have toxic, antifeedant and repellent properties against insects.

Azadirachtin, a complex tetranortriterpenoid limonoid from the neem seeds, is the main component responsible for both antifeedant and toxic effects in insects. Other limonoid and sulphur-containing compound with repellent, antiseptic, contraceptive, antipyretic and antiparasitic properties are found elsewhere in the tree, e.g. leaves, flowers, bark, roots.

The antifeedant effects of neem were the first to be described scientifically. In 1952, Heinrich Schmutterer recorded desert locusts (Schistocerca gregaria (Forskal)) refusing to feed on neem. Closer studies revealed that this species has an unusually high sensitivity to azadirachtin as an antifeedant, perhaps related to the supposed co-evolutionary origins of both tree and locust in Burma. there have been at least six international conferences on neem to date, the first taking place in Germany in 1980, and there is a vast scientific literature which reveals both the antifeedant effects of neem and the more important physiological effects (as far as crop protection is concerned). An important volume 'The Neem Tree' edited by schmutterer (1995)* summarizes knowledge of the tree to date.

This article reviews the important behavioral and physiological properties of azadirachtin, the main active ingredient of neem seeds. It also describes work carried out to date to identify its mode of action at the cellular level and differential effects between animal phyla which point to its potential success as safe insecticide.

\section{Chemistry}

The active ingredient azadirachtin was isolated from the seeds of A. indica by David Morgan (Butterworth and Morgan 1968) and its full structural determination was completed some $17 \mathrm{~b}$ yeas later concurrently in the laboratories of Steven Ley, W Kraus and K Nakanishi (Bilton et al. 1987, Kraus et al. 1987, Turner et al. 1987) (Fig.1).

A. indica produces a plethora of triterpenoids, the biosynthesis of which culminates in azadirachtin. The biosynthesis of azadirachtin starts with a steroid precursor (e.g. tirucallol) azadirone, azadiradione) and C-ring opening (e.g.nimbin, salannin), after which further and proseeds via two mais levels of structural complexity: furan ring formation (e.g. modifications yield azadirachtin (Rembold 1989, Ley et al. 1993).

Comparison of the antifeedant and toxic

\footnotetext{
* a new edition is presently being written.
} 


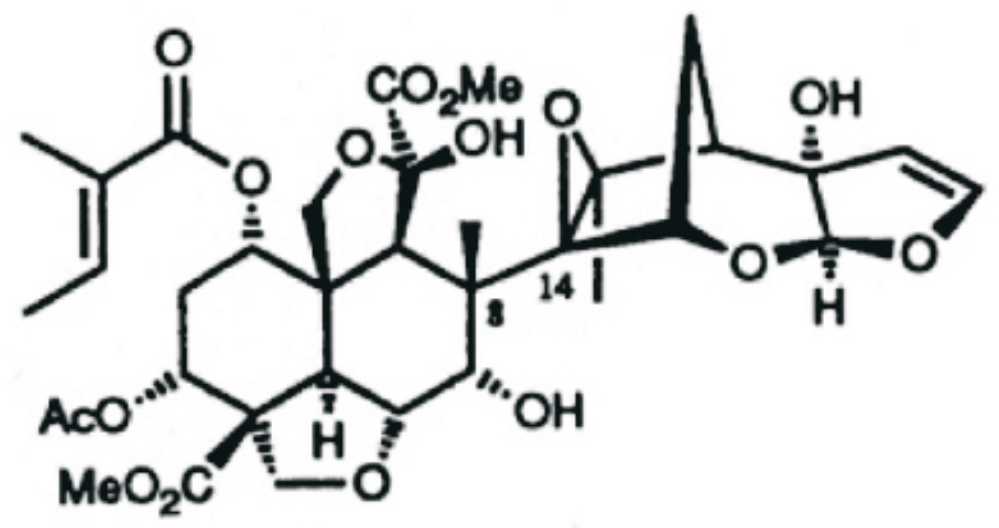

Figure 1. The azadirachtin molecule.

properties of azadirachtin with various less structurally complex putative biosynthetic precursors against larvae of Spodoptera littoralis (Boisd.), S. gregaria and Oncopeltus fasciatus Dallas (milkweed bug) has shown that toxicity to insects (severe growth and moult disruption) was only observed with azadirachtin. The less complex, less highly oxygenated molecules were shown to be ineffective in this manner (Aerts \& Mordue (Luntz) 1997). However, antifeedancy is found in compounds at lower levels of structural complexity, particularly against lepidoptera e.g. S. littoralis that are extremely sensitive to the presence of plant secondary compounds in their diet. Thus, there would appear to be no explicit link between antifeedant activity and toxicity of individual neem triterpenoids along the biosynthetic pathways to azadirachtin. In addition, for azadirachtin itself, whereas the toxic insect growth regulatory (IGR) effects are seen in all species, antifeedancy varies markedly between Insect Order and species within orders (Mordue (Luntz) \& Blackwell 1993).

Neem insecticides, which are extracts of neem seeds, contain many related triterpenoids in addition to azadirachtin including 3-tigloyl-azadirachtin (Azadirachtin B), nimbin and salannin. Their efficacy is directly related to azadirachtin content however many of the other compound also have biological activity and add to its effects. whereas pure azadirachtin has been shown to be effective in the field (Mordue et al. 1997) the natural mixtures of azadirachtins in neem insecticides may usefully mitigate against the development of resistance compared to azadirachtin alone (Feng \& Isman 1995).

\section{Effects on feeding}

Insects from different Orders differ markedly in their behavior responses to azadirachtin (Table 1). Lepidoptera are extremely sensitive to azadirachtin and show effective antifeedancies from $<1-50 \mathrm{ppm}$, depending upon species. Coleoptera, Hemiptera and Homoptera are less sensitive to azadirachtin behaviorally with up to $100 \%$ antifeedancy being achieved at 100-600 ppm although there are some aphid species which 
Table 1. Behavioural sensitivity of insects to azadirachtin: the effective dose $\left(\mathrm{ED}_{50}\right)$ which causes $50 \%$ inhibition of feeding.

\begin{tabular}{lc}
\hline & $\mathrm{ED}_{50}(\mathrm{ppm})$ \\
\hline Lepidoptera & $<0.001-50$ \\
Coleoptera & $100-500$ \\
Hemiptera & $100-500$ \\
Hymenoptera & $100-500$ \\
Orthoptera & $0.001->1000$ \\
\hline
\end{tabular}

also show behavioral sensitivity e.g. strawberry aphid. The Orthoptera show an enormous range in sensitivity from $S$. gregaria (a polyphagous species which has chemoreceptors finely tuned to many plant secondary compounds) to Locusta migratoria (L.) (a graminaceous species which does not have chemoreceptors tunes to feeding deterrents) to the extreme insensitivity of Melanoplus sanguinipes (Fab.), the North American Plains grasshopper which is an evolutionary sense has never encountered $A$. indica and has no chemoreceptors responding to azadirachtin. Such 'primary' (or gustatory) antifeedancy - 'the inability to ingest resulting from the perception of the antifeedant at a sensory level' (Schmutterer 1985), is responsible for crop protection in several species of Lepidoptera and S. gregaria. Desert locusts ( $S$. gregaria) are very sensitive to azadirachtin and fail to feed on sugar impregnated discs when the compound is present at concentrations of $0.01 \mathrm{ppm}$ and above (Mordue (Luntz) et al. 1996). Azadirachtin sprayed onto barley seedlings infested with $S$. gregaria nymphs protect plants at low doses (2 ppm) (Nasiruddin \& Mordue(Luntz) 1993). S. littoralis (African cotton leafworm), Spodoptera frugiperda (J.E. Smith)(fall armyworm), Heliothis virescens (F.) (tobacco budworm) and Helicoverpa armigera (Hüb.) (old world bollworm) also respond behaviorally to low concentrations of azadirachtin and are prevented from feeding on discs impregnated with the compound at concentrations of 0.1 $10 \mathrm{ppm}$ dependent upon species (Blaney et al. 1990, Simmonds et al. 1990, Mordue (Luntz) et al. 1998).

The antifeedant effects observed in these species are highly correlated with the sensory response of chemoreceptors on the insect mouthparts (Mordue (Luntz) et al. 1998). Feeding behavior depend upon both neural input from the insects chemical senses (taste receptor on tarsi, mouthparts and oral cavity) and central nervous integration of this 'sensory code'. Azadirachtin stimulates specific 'deterrent' cells in chemoreceptors and also blocks the firing of 'sugar' receptor cells, which normally stimulate feeding (Blaney et al. 1990, Simmonds et al. 1990, Mordue (Luntz) et al. 1999). This result in starvation and death oh these species by feeding deterrency alone.

In most other species of phytophagous insect however crop protection results from a combination of antifeedancy and physiological effects resulting from ingestion of azadirachtin. These physiological effects include 'secundary'antifeedancy whereby feeding is reduced post-ingestively. These "secondary" antifeedant effects include 'a reduction in food consumption and digestive efficiency subsequent to, and as a consequence of, ingestion, application or injection of the antifeedant' (Schmutterer 1985).

Such secondary antifeedant effects result from the disturbance of hormonal and/or other physiological system e.g. movement of food through the gut, inhibitions of digestive enzyme production, effects on the stomatogastric nervous system etc. Mordue (Luntz) et al. 1985, Koul \& Isman 1991, Timmins \& Reynolds 1992, Trumm \& Dorn 2000). For example locusts injected with azadirachtin, which by-passes the taste receptors, show a reduced ingestion of food as seen by faecal pellet production (Nasiruddin \& Mordue (luntz) 1993). Hemipteran insects feeding on tobacco seedlings which had been systemically treated with 500 ppm azadirachtin, were shown initially to feed 
normally but, after termination of the initial feed, the interval prior to the next subsequent feed was significantly increased and feeding activity thereafter was suppressed (Nisbet et al. 1993). Also aphids which had fed on artificial diets containing much lower concentration of azadirachtin (25 ppm) exhibited no signs of primary antifeedant effects during an initial $24 \mathrm{~h}$ period of access to the diets but their feeding rate fell dramatically in the subsequent $24 \mathrm{~h}$ period (Nisbet et al. 1994).

A consequence of interrupted feeding activity can be an effect on the ability of insects to transmit pathogens. Aphids require extended feeding periods to acquire persistentlytransmitted luteoviruses (e.g. potato leafroll virus, PLRV) from plants. Treatment of PLRVinfected tobacco plants with azadirachtin reduced sustained feeding by Mysus persicae (Sulzer) (peach-potato aphid) and reduced the ability of aphids to acquire and transmit PLRV. However, azadirachtin does not always reduce the spread of plant virus diseases by aphids. Treatment of uninfected seedlings with the same concentrations of azadirachtin (500 ppm) failed to prevent them from becoming infected when viruliferous aphids fed on them (Nisbet et al. 1996a). The successful infection of a plant with luteoviruses is dependent upon the transfer of aphid saliva to the plant, a process which may be brief by comparison with the time required for virus acquisition by the aphid, and is not overcome by the presence of the antifeedant. Similarly, azadirachtin failed to protect seedlings from infections with a nonpersistently transmitted potyvirus (potato virus y) from viruliferous aphids (Nisbet 1992).

\section{Effects on Physiology}

The physiological effects of azadirachtin are much more consistent than the antifeedant effects, and result from interference with growth and moulting, interference with reproduction and interference with cellular processes (Table 2). In all species tested dose response effects can be seen as reduced growth, increased mortalities, abnormal moults and delayed moults. These effects are related to disruption of endocrine system controlling growth and moulting. The moulting effects are due to a disruption in the synthesis and release of ecdysteroids (moulting hormone) and other classes of hormones and this can be demonstrated by accurately timed injections of azadirachtin into the haemoulymph of $\mathrm{v}^{\text {th }}$ instar nymphs of L. migratoria (Mordue (Luntz) et al. 1986). Measurements of haemolymphecdysteroid levels by radioimmunoassay (RAY) revealed the normal peak of hormone release at day 8 of an 11day instar. In those insects injected with azadirachtin before hormone release, ecdysteroid release is blocked entirely and the insects die before the moult after an extended instar; in those injected at the start of ecdysone release, the peak is delayed and its decline slow down. This prevents the release of eclosion hormone which controls the motor programme of eclosion or moulting and these insects also die before the moult. Finally, if injected at the peak of ecdysone release moult initiation proceeds but the insects die during ecdyses unable to swallow enough air to extricate themselves from the old cuticle (Plates $1 \mathrm{a}-\mathrm{c})$.

In all species investigated, physiological effects can be measured as growth reduction, increased mortality and abnormal and delayed moults. Such endocrine disruption effects can be demonstrated very effectively in $O$. fasciatus. Azadirachtin applied topically in acetone to $O$. fasciatus $\mathrm{v}^{\text {th }}$ instar nymphs show a linear, concentration dependent relationship when the various IGR effects are totalled (Fig. 2a, b) (Mordue (Luntz) et al 1995).

The physiological effects of azadirachtin can be categorized in two ways:

i. Indirect Effects - exerted via the endocrine system. The neurosecretory system of the brain affected by azadirachtin which causes a blockage of the realese of morphogenetic peptide hormones e.g. PTTH (prothoracicotropic hormone) and allatostatins. These 
Table 2. The overall effects of azadirachtin against insects.

\begin{tabular}{|c|c|c|}
\hline Effects & Target & Mode of action \\
\hline $\begin{array}{l}\text { Primary } \\
\text { antifeedancy }\end{array}$ & $\begin{array}{l}\text { Mouthpart \& other } \\
\text { chemoreceptors }\end{array}$ & $\begin{array}{l}\text { Deterrent cell stimulation } \\
\text { Sugar cell inhibition }\end{array}$ \\
\hline $\begin{array}{l}\text { Secondary } \\
\text { antifeedancy }\end{array}$ & Gut & $\begin{array}{l}\text { Peristalsis inhibited } \\
\text { Enzyme production reduced } \\
\text { Midgut cells not replaced }\end{array}$ \\
\hline $\begin{array}{l}\text { Insect growth } \\
\text { regulation }\end{array}$ & Cuticle & $\begin{array}{l}\text { Alterations to ecdysteroid and } \\
\mathrm{JH} \text { titres by blockage of release } \\
\text { of morphogenetic peptides leading } \\
\text { to moulting defects }\end{array}$ \\
\hline Sterility & Reproductive organs & $\begin{array}{l}\text { Alterations to ecdysteroid and } \mathrm{JH} \\
\text { titres leading to reduction in } \\
\text { number of viable eggs and live } \\
\text { progeny }\end{array}$ \\
\hline \multirow[t]{3}{*}{ Cellular processes } & Dividing cells & $\begin{array}{l}\text { Blockage of cell division post } \\
\text { metaphase in meiosis and mitosis }\end{array}$ \\
\hline & Muscles & Loss of muscle tone \\
\hline & Cell synthetic machinery & $\begin{array}{l}\text { Blockage of digestive enzyme } \\
\text { production in gut } \\
\text { Inhibition of protein synthesis } \\
\text { in various tissues }\end{array}$ \\
\hline
\end{tabular}

control the function of the prothoracic glands and the corpora allata respectively. Moulting hormone (â-hydroxyecdysone) from the prothoracic glands in turn controls new cuticle formation and ecdyses (the act of extrication from the old cuticle) whereas juvenile hormone $(\mathrm{JH})$ from the corpora allata controls the formation of juvenile stages at each moult. In the adult both hormones can be involved in the control of yolk deposition in the eggs. Any disruption in these cascade events by azadirachtin results in the many various but well-defined effects seen as moult disruption, moulting defects and sterility effects.

ii. Direct Effects - on cells and tissues. Azadirachtin is taken up into cells and causes inhibition of both cells division and protein synthesis. Such effects are seen in flaccid paralysis of muscles, midgut cells necrosis and loss of nidi (regenerative cells) of the gut and lack of midgut enzyme production.

The sum total of the physiological effects of azadirachtin is consistent throughout species when compared to antifeedant effects. An $\mathrm{ED}_{50}$ of around $1 \mathrm{mg} / \mathrm{g}$ body weight is seen though the many insects species 

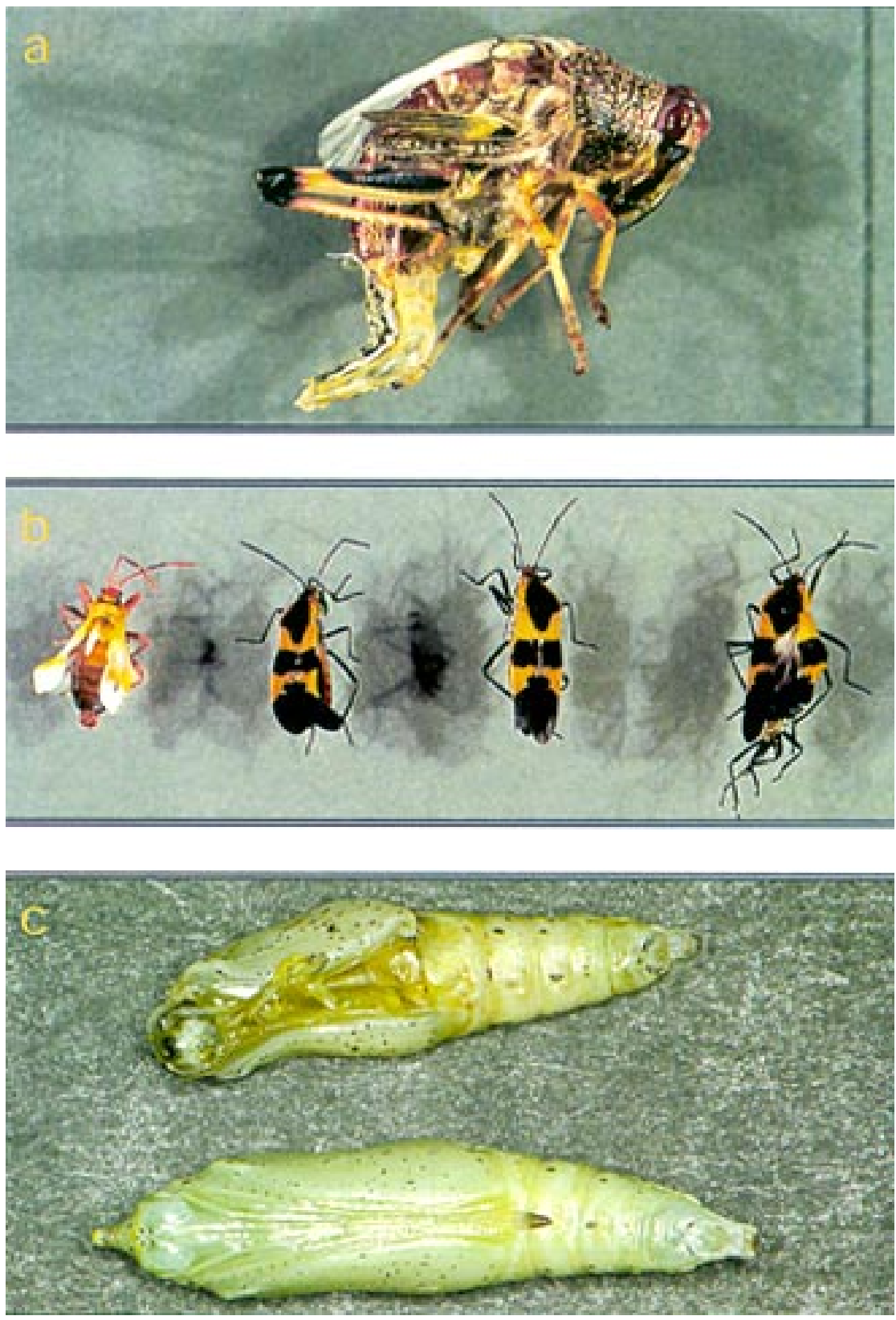

Plate 1. Moulting abnormalities caused by azadirachtin treatment. a - desert locust ( $S$. gragaria) showing death at ecdysis (x 1.5); b - milkweed bug (O. fasciatus) showing moulting defects (x 1.5); c - cabbage white butterfly (P. brassicae) showing abnormal (top) vs. normal pupa (bottom) (x 3). 


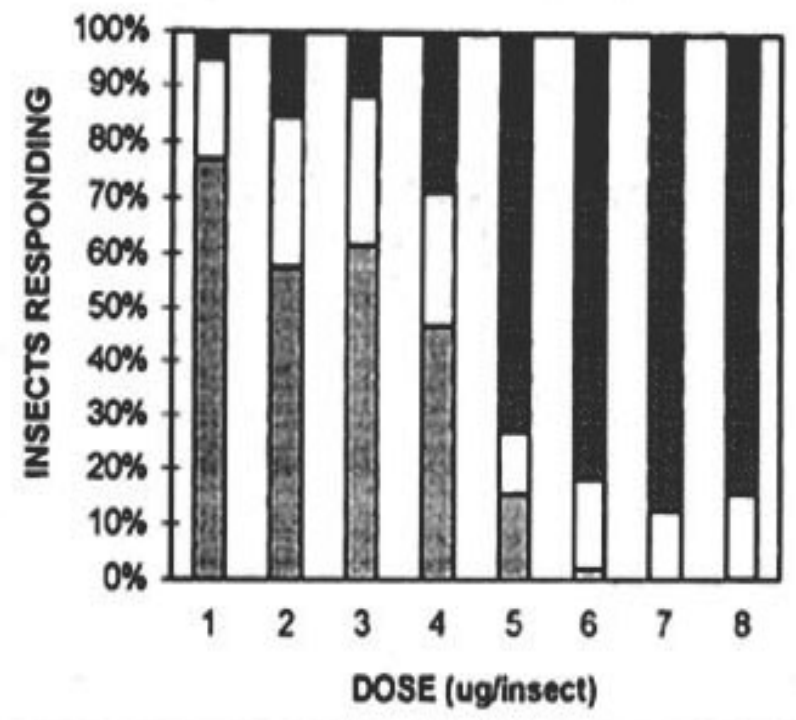

(a)

[ Normal moult a Mortalities a Abnormal moult a Delayed mouk

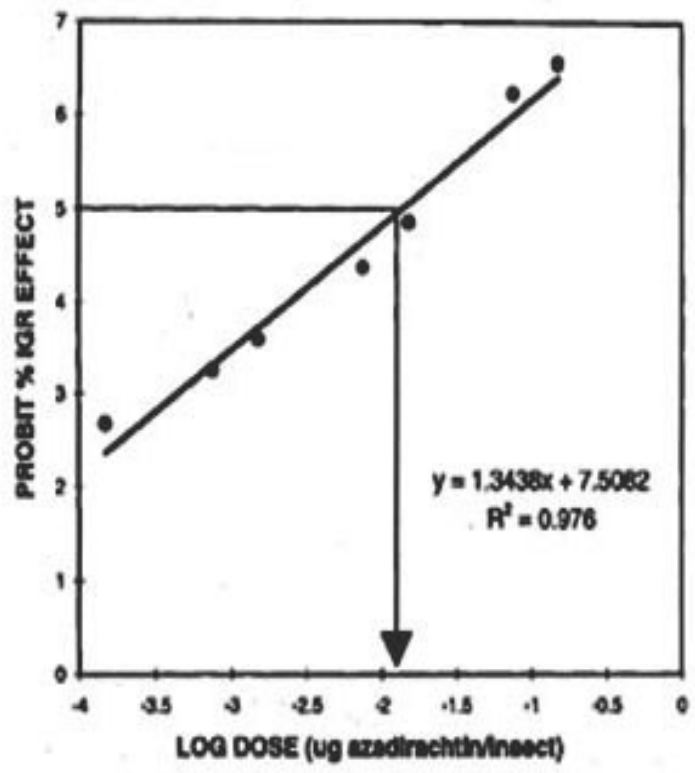

(b)

Figure 2. (a) IGR effects of $O$. fasciatus fifth instar nymph treated with azadirachtin on day one of the $\mathrm{v}^{\text {th }}$ instar showing normal moults decreasing with dose as a range of IGR effects appear. $\mathrm{n}=50-100 /$ conc. $1=$ control; Dose 2-8 $=0.00015,0.00075,0.0015,0.0075,0.015$, $0.075,0.15 \mu \mathrm{g}$ azadirachtin/insect respectively. (b) Azadirachtin IGR dose response curve using the total effects as described in (a). 
tested (Mordue (Luntz) \& Blackwell 1993).

\section{Effects on Reproduction}

When the primary antifeedant properties do not operate due to low sensitivity of chemoreceptors or are circumvented by injection or applying the compound topically, azadirachtin can be shown to cause profound effects on the reproductive process of both male and female insects. For example, in $L$. migratoria azadirachtin inhibits both oogenesis and ovarian ecdystereroid synthesis so preventing oviposition (Rembold \& Sieber 1981). Aphids are insensitive to the primary antifeedant effects of azadirachtin below 100 ppm, although secondary antifeedant effects are observed (Nisbet et al. 1994). When female aphids are fed on diets containing low concentrations of azadirachtin (5ppm), their fecundity decreases dramatically within $48 \mathrm{~h}$ of feeding and, if they were fed in diets containing more than $10 \mathrm{ppm}$ azadirachtin any nymphs which were produced were non-viable (Mordue (Luntz) et al. 1996).

Male reproduction is also affected by azadirachtin. Injection of male $O$. fasciatus with $0.125 \mathrm{mg}$ per insect severely reduces male potency as seen by a $80 \%$ reduction in the fecundity of normal females when mated with treated males (Dorn 1986). Testes dimensions of male desert locusts injected with low concentrations of azadirachtin during their development were significantly reduced and the meiotic processes which are responsible for the production of mature sperm in adult males were interrupted. Blockage of cell divisions was shown to occur prior to metaphase (Linton et al. 1997). Metaphase is the stage of cell division at which microtubules form the spindle apparatus prior to the physical separation of homologous pairs of chromosomes to opposite at this stage in cell division suggest that cell microtubular events may have been affected by azadirachtin (Mordue (Luntz), Mordue \& Nibetunpublished).

\section{Understanding the Effects of Azadirachtin on Insects}

The primary antifeedant effects Lof azadirachtin on insects are produced by the stimulation of specific deterrent chemoreceptors on the mouthparts together with an interference of the perception of phagostimulants by other chemoreceptors (Mordue (Luntz) et al. 1998). The secondary effects on feeding, developmental and reproductive disruption are caused by effects of the molecule directly on somatic and reproductive tissues and indirectly through the disruption of endocrine processes. Research is now being carried out to understand the effects of azadirachtin at the cellular level in insect tissues.

In mature adult male $S$. gregaria, a tritiumlabeled azadirachtin derivative, $\left(\left[22,23-{ }^{3} \mathrm{~h}_{2}\right]\right.$ dihydroazadirachtin), was shown to bind specifically to several tissues but the most intense binding per unit of protein was in preparation from testes. This binding was almost $\left(\mathrm{k}_{\mathrm{d}} 8.7 \mathrm{nM}\right)$ and essentially irreversible (Nisbet et al. 1995). Localisation of the binding by autoradiography revealed preferential binding in the testes follicles, localized on the tails of developing sperm. This binding was therefore associated with one of the subcellular components of the developing sperm tail; membrane, axoneme or mitochondrial body (Nisbet et al. 1996b).

Sub-cellular fractionation of Sf9 cells (captured insect cells derived from $S$. frugiperda) incubated with $\left[22,23-{ }^{3} \mathrm{H}_{2}\right]$ dihydroazadirachtin during logarithmic growth phase revealed high affinity specific binding to the nuclear fraction of the cells (Nisbet et al. 1997). A comparison of binding of tritiated dihydroazadirachtin to these two insect tissues shows specific, time-dependent, saturable high affinity binding in both tissues, with many similarities in binding characteristics (Table 3). Preliminary characterization of the binding sites has indicated that it is proteinaceous, heat-labile and may be associated with cellular RNA 
(Mordue (luntz) et al. 1999). Unsuccessful attempts to solubilise the protein and extract it for identification by ligand binding assays to fully characterise the azadirachtin binding sites are presently being carried out using insect cell lines.

Table 3. Binding characteristics of tritiated dihydroazadirachtin to Schistocerca gragaria testes and Spodoptera Sf9 cells.

\begin{tabular}{lcc}
\hline Binding parameter & \multicolumn{2}{c}{ Characteristic } \\
\cline { 2 - 3 } & S.g.testes & Sf9 cells \\
\hline $\begin{array}{l}\text { Specificity } \\
\text { (as \% of total binding) }\end{array}$ & $94 \%$ & $97 \%$ \\
Time dependence & & \\
equílibrium binding & & $60 \mathrm{~min}$ \\
association constant $\left(\mathrm{K}_{\mathrm{lbs}}\right)$ & $0.03 \mathrm{~min}$ & $0.04 \mathrm{~min}$ \\
Semipermanence & & \\
dissociation rate constant $\left(\mathrm{K}_{-1}\right)$ & $0.004 \mathrm{~min}{ }^{1}$ & $0.007 \mathrm{~min}^{-1}$ \\
Saturability & & \\
Receptor affinity $\left(\mathrm{K}_{\mathrm{d}}\right)$ & $8.7 \mathrm{nM}$ & $18.1 \mathrm{nM}$ \\
Receptor number $\left(\mathrm{B}_{\max }\right)$ & $0.3 \mathrm{pmol} / \mathrm{mg}$ & $23.9 \mathrm{pmol} / \mathrm{mg}$ \\
& & \\
Site of action & Cell division & $\mathrm{Nuclei}$ \\
& maturing sperm tails & \\
\hline
\end{tabular}

suggests that its 3-dimensional integrity within membranes is essential for its activity. Azadirachtin prevents the proliferation of Sf9 cells in vitro and alters both the protein content and abundance in those cells (Fig. 3 (Barry, Sternberg \& Mordue (Luntz) unpublished), Rembold \& Annadurai 1993). It therefore appears from these observations that azadirachtin operates at the cellular level by disrupting protein synthesis and secretion events and, more fundamentally, at the molecular level by altering or preventing the transcription of proteins expressed during and/ or translation of proteins expressed during periods of rapid protein synthesis e.g. in dividing cells or cells forming new assemblages of organelles or cytoskeleton. Ongoing studies

\section{Differential Effects in Insects and Non-Target Organisms}

In order to fully understand the mechanisms by which azadirachtin operates, the differential effects of azadirachtin must be distinguished:

i. in insects, to help decide which are the significant lesions involved in its mode of action.

ii. in other non-target organisms e.g. vertebrates to make quite certain that the margin for insecticide use is real and defined.

Two examples here related to firstly the effects of azadirachtin on locust excretory mechanisms and secondly to the effects on 


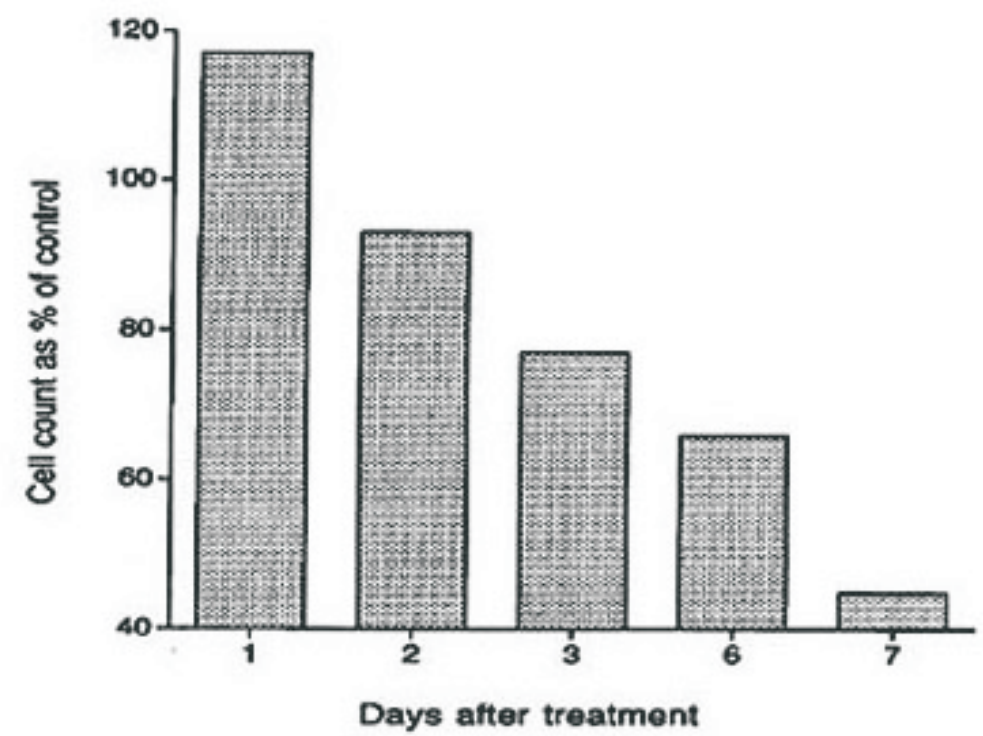

Figure 3. Inhibition of Spodoptera Sf9 cell proliferation after treatment with $10 \mu \mathrm{M}$ azadirachtin. (Sf9 cells were cultured in Graces cultured medium, supplemented with FCS. Azadirachtin was added in DMSO, final concentration 1\%, and cell numbers were counted at $24 \mathrm{~h}$ intervals thereafter).

vertebrate cultured neurons. Studies with tritiated dihydroazadirachtin had indicated that azadirachtin accumulated in high amounts in Malpighian tubules, the excretory organs of insects (Rembold et al. 1988). Such concentrations must be associated with excretion of azadirachtin but also may be associated with its mode of action, it has been shown that azadirachtin reduces both basal and diuretic peptide-stimulated urinary secretions in locusts (Fig. 4), and that the reduction in stimulated urine levels is induced through inhibition of cyclic AMP (cAMP) regulated processes (Mordue (Luntz), Coast, Mordue \& Nisbet unpublished). This reduction however, occurs in the presence of azadirachtin at mM levels only, with the threshold response being close to this, i.e. at levels some 1000 fold less sensitive than more established azadirachtin effects (e.g.
Rembold \& Annadurai 1993). Azadirachtin treated insects do become slightly bloated whit time post-treatment (Cottee \& Modue (Luntz) 1982, Nasiruddin \& Mordue (Luntz) 1993) presumably as a result of lesions to the Malpighian tubules, however it is very clear that lack of diuresis by the cAMP secondary messenger cascade is not the main mode of action of azadirachtin.

In vertebrate cell lines, small but significant azadirachtin effects have been shown to occur on rat cultured neurons where effects on $\mathrm{K}^{+}$conductances are seen at $10^{-5}$ and $10^{-4} \mathrm{M}$ azadirachtin (Scott et al. 1999). This is however, some one thousand times more insensitive than effects of azadirachtin on insect sensory systems (Simmonds et al. 1995). Similarly, when looking at other mammalian cell lines, protein synthesis of mouse mammary acini was shown to be 


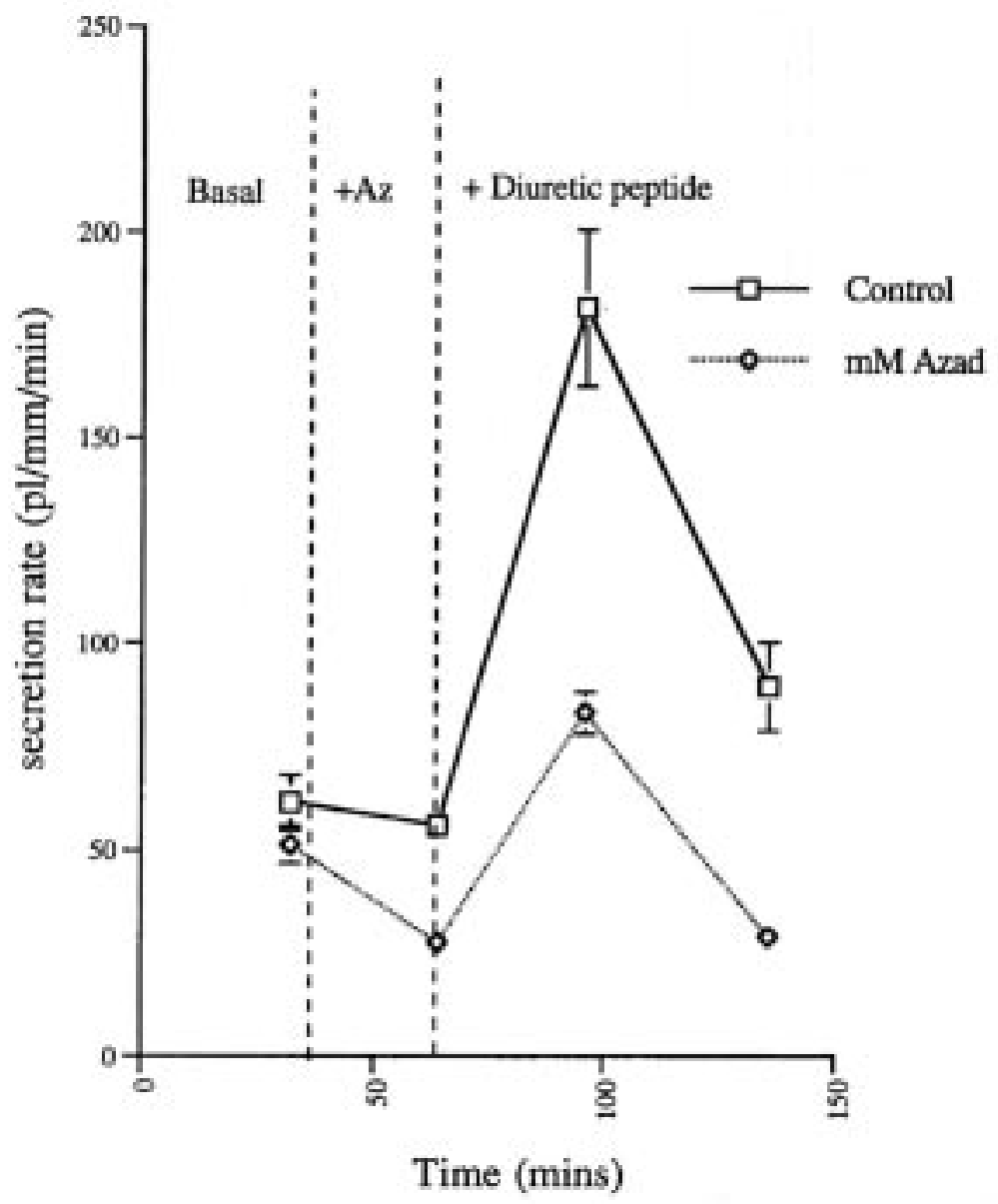

Figure 4. The effect of $\mu \mathrm{M}$ azadirachtin on basal and stimulated fluid secretion rates by $S$. gregaria Malpighian tubules in vitro. (Individual tubules of defined length were set up in saline and the cut end isolated in liquid paraffin. Stimulus or solvent was applied to the saline (two ffs). Droplets of urine forming at the cut end of the tubules in the paraffin were collected against time and their volume calculated by measurement of diameters).

reduced by azadirachtin at $5 \times 10^{-6} \mathrm{M}$ (Nisbet, Duncan, Burgoyne, Mordue \& Mordue (Luntz) unpublished), some 500 times less sensitive than inhibition of protein synthesis in insects cell lines (Rembold \& Annadurai 1993). Direct comparisons of an insect and mammalian cell line also show marked differential effects of azadirachtin (Reed \& Majumdar 1998). Evidence is accumulating to show a highly significant difference in the effects of azadirachtin in insects and mammalian cell with mammalian cell being very insensitive to its effects. 
Neem an Azadirachtin in Insect Control

The complexity of the molecular structure of azadirachtin precluded its synthesis for pesticide use. Extracts of neem seeds containing azadirachtin together with several structurally related molecules have formed the basis of neem usage in insect control (Isman 1997). Future approaches may also include the production of azadirachtin for insect control by in vitro tissue cultures of neem (Allan et al. 1994, 1999). Neem insecticides are effective mainly as insect growth regulates and sterilants, against a broad spectrum of pest insects. Crude neem extracts have been used at a local, small-farm level for some time in countries where neem grows indigenously or where plantations have been established. In the major western countries of the world such as the USA and Canada and in Europe few commercial neem insecticides have reached the market place to date. Progress has been hampered by lack of supplies of neem kernels of known azadirachtin content, by lack of standardization of formulated products, by cost of the product and by lack of regulatory approval of the complex mixture of compounds found in neem extracts. Until recently these problems had meant that neem insecticides had not generated much impact on the marketplace. Times, however, may well be changing.

With the resolution of many of the problems of supply and standardization, the full regulatory approval of neem insecticides by the USA and now in Germany for use on potatoes, apples and tomatoes, much field data is being generated which are establishing neem insecticides as viable alternatives to more conventional approaches, particularly in integrated pest management system. Now that it is realized that disruption of growth and reproduction rather then antifeedancy are the main characteristic of pest control, neem is being used in the field at lower concentrations than those originally recommended (>100 ppm ai). Treatment of artificial diet with levels as low as 5 ppm or 0.25 ppm azadirachtin have been shown to significantly reduce reproduction output in $M$. persicae (Mordue (Luntz) et al. 1996), and feeding growth and development in S. littoralis (Martinez \& van Emden 1999) respectively. The value of low concentrations of neem in pest control has generated research into combined approaches using both neem and beneficial species. In the laboratory using $M$. persicae and its parasitoid Encarsia formosa 5 ppm azadirachtin treatments of leaf discs together with $E$. Formosa produce additive effects compared with either approach separately and can entirely prevent nymph production of $M$. persicae (Fig. 5) (Sugden, Armstrong \& Mordue (Luntz) unpublished). In the field and in more complex laboratory situations, however, such results are more difficult to demonstrate. It would appear that there is a fine line between the level of azadirachtin required to affect the pest and the level which will not affect the parasitoid or predator (Belmain et al. 2000, Perera et al. 2000, Raguraman \& Singh 2000, Simmonds et al. 2000). Such integrated approaches to pest control however are an encouraging way forward for the use of neem pesticides.

Neem pesticides may also have a useful role to play in resistance management. It has been demonstrated that the effects of neem in reducing levels of detoxification enzymes (due to its blockage of protein synthesis) may make insecticides more effective in resistant strains of insect (Lowery \& Smirle 2000). Also, it has been shown in Bt resistant strains of Leptinotarsa decemlineata Say, the Colorado potato beetle, that $0.25 \%$ Neemix combined with Bacillus thuringiensis can act as a resistance breaking compound (Trisyono \& Whalon 2000). In this instance depending upon the resistance mechanism, the neem effects may be due also to blockage of enzyme production, or to the reduced midgut cell turnover rate (Nasiruddin \& Mordue (Luntz) 1993).

\section{Conclusions}

Azadirachtin from neem effects insects in 


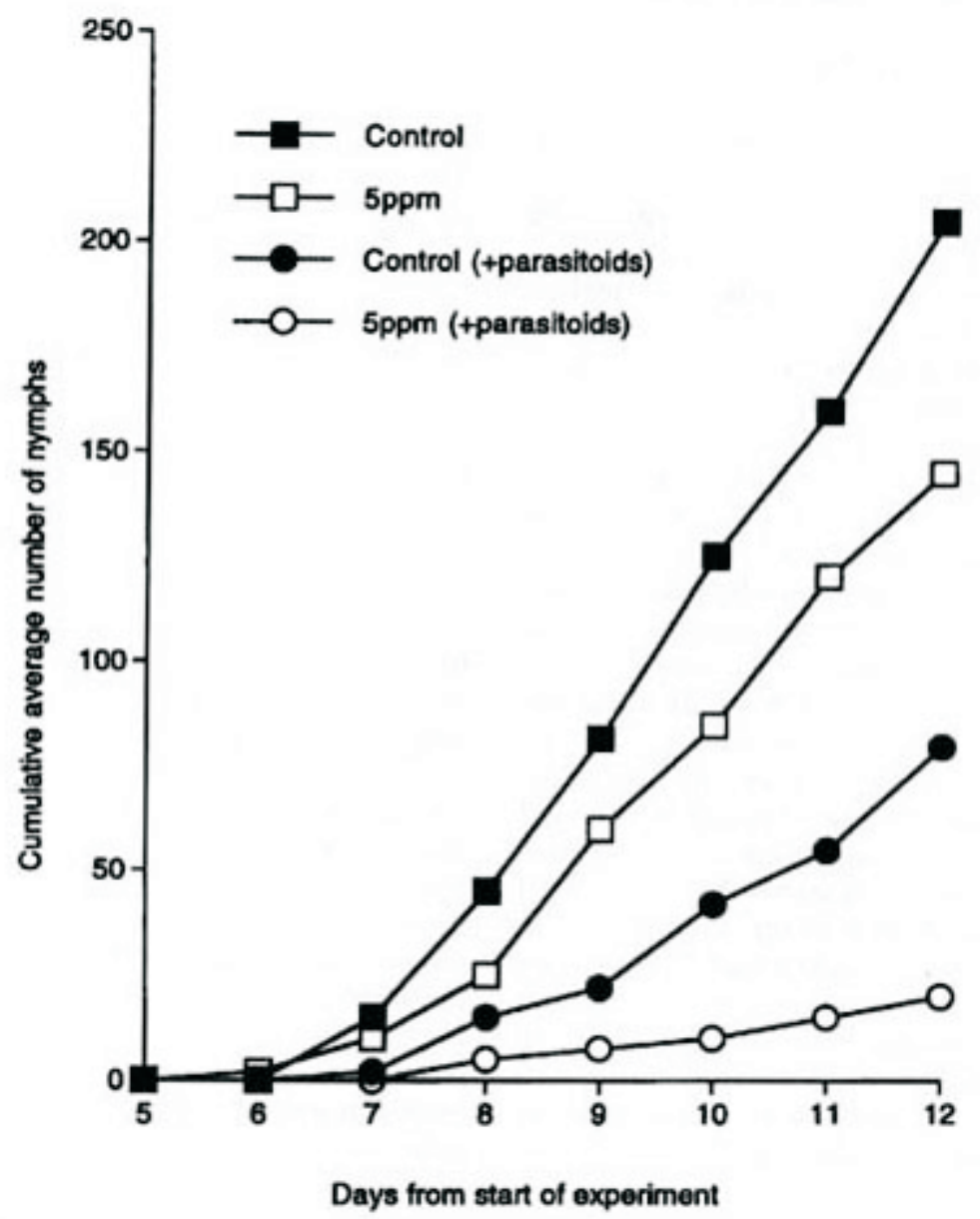

Figure 5. Cumulative numbers of nymphs produced by $M$. persicae on azadirachtin treated leaf discs with or without parasitoid challenge by E. formosa. (Leaves were coated with $5 \mathrm{ppm}$ azadirachtin or water (+ wetter).

a variety of different ways: as an antifeedent, insect growth regulator and sterilant. As antifeedant sensitivity varies greatly between insects the overriding efficacy of neem insecticide use lies in its physiological toxic effects. An understanding of the physiological effects of azadirachtin in neem has been reached and biochemical approaches have begun to define its mode of action at the cellular level. Further work is however required to fully understand its mode of action. It is now accepted that neem insecticides have a wide margin of safety for both user and consumer. Increasing knowledge of how to use neem insecticides in the field is proving a solid base from which successful market 
penetration should be achieved.

\section{Acknowledgments}

The BBSRC, University of Aberdeen and S.V. Ley are acknowledged for support (AJN).

\section{Literature Cited}

Allan, E.J., P. Eeswara, S. Johnson, A.J. Mordue (Luntz), E.D. Morgan \& T. Stuchbury. 1994. The production of azadirachtin in-vitro tissue culture of neem, Azadirachta indica. Pestic. Sci. 42: 147-152.

Allan, E.J., T. Stuckbury \& A.J. Mordue (Luntz). 1999. II Azadirachta indica A. Juss. (Neem tree): In vitro culture, micropropagation, and the production of azadirachtin and other secondary metabolites. Biotec. Agric. For. 43: 1141.

Aerts, R.J. \& A.J. Mordue (Luntz). 1997. Feeding deterrence and toxicity of neem triterpenoids. J. Chem Ecol. 23: 2117 2133.

Blaney, W.M., M.S.J. Sommonds, W.V. Ley, J.C. Anderson \& P.L. Toogood. 1990. Antifeedant effects of azadirachtin and structurally related compounds on lepidopterous larvae. Entomol. Exp. Appl. 55: 149-160.

Bilton, J.N., H.B. Broughton, P.S. Jones, S.V. Ley, Z. Lidert, E.D. Morgan, H.S. Rzepa, R.N. Sheppard, A.M.Z. Slawin \& D.J. Williams. 1987. An X-ray crystallographic, mass spectroscopic, and NMR study of the limonoid insect antifeedant azadirachtin and related derivatives. Tetrahedron 43: 2805-2815.

Butterworth, J.H. \& E.D. Morgan. 1968. Isolation of a substance that suppresses feeding in locusts. J. Chem. Soc., Chem. Commun.: 23-24.
Cottee, P.K. \& A.J. Mordue (Luntz). 1982. An investigation into the physiological actions of feeding deterrents. Proc. $5^{\text {th }}$ Int. Symp. Insect-Plant Relationships, Wageningen, p.379-380.

Dorn, A. 1986. Effects of azadirachtin on reproduction and egg development of the heteropteran Oncopeltus fasciatus Dallas. J. Appl. Entomol. 102: 313-319.

Feng, R. \& M.B. Isman. 1995. Selection for resistance to azadirachtin in the green peach aphid Myzus persicae. Experientia 51:831-833.

Isman, M.B. 1997. Neem insecticides. Pest. Outlook: 32-38.

Koul, O. \& M.B. Isman. 1991. Effects of azadirachtin on the dietary utilization and development of the variegated cutworm Peridroma saucia. J. Insect. Physiol. 37: 591-598.

Kraus, W.,M. Bokel, A. Bruhn, R. Cramer, I. Klaiber, A.Klenck, G. Nagl, H. Pöhnl, H. Sadlo \& B. Vogler. 1987. Structure determination by NMR of azadirachtin and related compounds from Azadirachta indica (Meliaceae). Tetrahedron 43: 2817-2830.

Ley, S.V., A.A. Denhom \& A. Wood. 1993. The chemistry of azadirachtin. Nat. Prod. Rep.: 109-157.

Linton, Y.M., A.J. Nisbet \& A.J. Mordue (Luntz). 1997. The effects of azadirachtin on the tests of the desert locust, Schistocerca gragaria. J. Ins. Physiol. 43: 1077-1084.

Lowery, D.T. \& M.J Smirle. 2000. Toxicity of insecticides to obliquebanded leafroller, Choristoneura rosaceana, larvae and adults exposed previously to neem seed oil. Entomol. Exp. Appl. 95: 201-207. 
Martinez, S.S. \& H.F. van Emden. 1999. Sublethal concentrations of azadirachtin affect food intake, conversion efficiency and feeding behaviour of Spodoptera littoralis (Lepidoptera: Noctuidae). Bull. Entomol. Res. 89: 65-71.

Mordue (Luntz), A.J. \& A. Blackwell. 1993. Azadirachtin: An update. J. Insect Physol. 39: 903-924.

Mordue (Luntz), A.J., P.K. Cottee \& K.A. Evans. 1985. Azadirachtin: Its effect on gut motility, growth and moulting in locusta. Physiol. Entomol. 10: 431-437.

Mordue (Luntz), A.J., K.A. Evans \& M. Charlet. 1986. Azadirachtin, ecdysteroids and ecdysis in Locusta migratoria. Comp. Biochem. Physiol. 85c: 297-301.

Mordue (Luntz), A.J., G. Davidson, R.G. McKinlay \& J. Hughes. 1995. Observations on azadirachtin for the management of cabbage caterpillar infestation in the field. BCPC symp. Proceed. 63: 371-378.

Mordue (Luntz), A.J., A. Zounos, I.R. Wickramananda \& E.J. Allan. 1995. Neem tissue culture and the production of insect antifeedant and growth regulatory compounds. BCPC Symp. Proceed. 63: 187-194.

Mordue (Luntz), A.J., A.J. Nisbet, M. Nasiruddin \& E. Walker. 1996. Differential thresholds of azadirachtin for feeding deterrence and toxicity in locusts and an aphid. Entomol. Exp. Appl. 80: 69-72.

Mordue (Luntz), A.J., M.S.J. Simmonds, S.V. Ley, W.M. Blaney, W. mordue, M. Nasiruddin \& A.J. Nisbet. 1998. Actions of azadirachtin, a plant allelochemical, against insects. Pestic. Sci. 54: 277-284.
Mordue (Luntz), A.J., A.J. Nisbet, L. Jennens, S.V. Ley \& W. Mordue. 1999. Tritated hihydroazadirachtin binding to Schistocerca gregaria testes and Spodoptera Sf9 cells suggests a similar cellular mechanism os action for azadirachtin, p.247-258. In R.P. Singh \& R.C. Saxena (eds.), Azadirachta indica, A. Juss. Int. Neem Conference, Gatton, Australia 1996. Oxford \& IBH Publ. Co. PVT Ltd.

Nasiruddin, M. \& A.J. Mordue (Luntz). 1993. The effect azadirachtin on the midgut histology of the locusts, Schistocerca gregaria and Locusta migratoria. Tissue Cell 25: 875-884.

Nisbet, A.J. 1992. The effect of azadirachtin on the feeding behaviour and virus transmission of Myzus persicae (Sulzer). $\mathrm{PhD}$ thesis, University of Glasgow, 312p.

Nisbet, A.J., J.A.T. Woodford, R.H.C. Strang \& J.D. Connolly. 1993. Systemic antifeedant effects of azadirachtin on the peach-potato aphid Myzus persicae. Entomol. Exp. Appl. 68: 87-98.

Nisbet, A.J., J.A.T. Woodford, R.H.C. Strang. 1994. The effects of azadirachtin-treated diets on the feeding behaviour and fecundity of the peachpotato aphid, Myzus persicae. Entomol. Exp. Appl. 71: 65-72.

Nisbet, A.J., A.J. Mordue (Luntz) \& W. Mordue. 1995. Detection of $\left[22,23-{ }^{3} \mathrm{H}_{2}\right]$ dihydroazadirachtin binding sites on membranes from Schistocerca gregaria (Forskål) testes. Ins. Biochem. Molec. Biol. 25: 551-558.

Nisbet, A.J., J.A.T Woodford \& R.H.C Strang. 1996a. The effect of azadirachtin on the acquisition and inoculation of potato leafroll virus by Myzus persicae. Crop Prot. 15: 9-14. 
Nisbet, A.J., A.J. Mordue (Luntz), W. Mordue, L.M. Williams \& L. Hannah. 1996b. Autoradiographic localisation of $\left[22,23-{ }^{3} \mathrm{H}_{2}\right]$ dihydroazadirachtin binding sites in desert locusts testes. Tissue Cell 28: 725-729.

Nisbet, A.J., A.J. Mordue (Luntz), R.B. Grossman, L. Jennens, S.V. Ley \& W. Mordue. 1997. Characterisation of azadirachtin binding to Sf9 nuclei in vitro. Arch. Inst. Biochem. Physiol. 34: 461473.

Perera, D.R., G. Armstrong \& N. Senanayake. 2000. Effect of antifeedants on the diamondback moth (Plutella xylostella) and its parasitoid Cotesia plutellae. Pest Manage. Sci. 56: 486-490.

Raguraman, S. \& R.P. Singh. 2000. Biological effects of neem (Azadirachta indica) seed oil on an egg parasitoid, Trichogramma chilonia. J. Econ. Entomol.92: 1274-1280.

Reed, E. \& S.K. Majumdar. 1998. Differential cytotoxic effects of azadirachtin on Spodoptera frugiperda and mouse cultured cells. Entomol. Exp. Appl. 89: 215-221.

Rembold, H. 1989. Azadirachtins: Their structure and mode of action, p.150-163. In J.T.Arnason, B.J.R. Philogène \& P. Morand (eds.), Insecticides of plant origin. ACS Symp. Ser. 387 American Chemical Society, Washington, DC.

Rembold, H. \& K.P. Sieber. 1981. Inhibition of oogenesis and ovarian ecdysteroid synthesis by azadirachtin in Locusta migratoria migratorioides (R. \& F.). Z. Naturforsch. 36c: 466-469.

Rembold, H \& R.S. Annadurai. 1993. Azadirachtin inhibits proliferation of Sf9 cells in monolayer culture. Z.
Naturforsch. 48c: 495-499.

Schmutterer, H.1985. Which insect pests can be controlled by application of neem seed kernel extract under field conditions. Z. Angew. Entomol. 100: 468-475.

Schmutterer, H. (ed) 1985. The neem tree Azadirachtia indica A. Juss and other meliaceous plants: Sources of unique natural products for integrated pest management, medicine, industry and other purposes. $\mathrm{VCH}$, Weinheim, Germany, 696p.

Scott, R.H., K. O'Brien, L. Roberts, W. Mordue \& A.J. Mordue (Luntz). 1999. Extracellular and intracellular actions of azadirachtin on the electrophysiological properties of cultured rat DRG neurons. Comp. Biochem. Physiol. 123: 85-93.

Simmonds, M.S.J., W.M. Blaney, S.V. Ley, J.C. Anderson \& P.L. Toogood. 1990. Azadirachtin: Structural requirements for reducing growth and increasing mortality in lepidopterous larvae. Entomol. Exp. Appl. 55: 169-181.

Simmonds, M.S.J., W.M. Blaney, S.V. Ley, J.C. Anderson, R. Banteli, A.A. Denholm, P.C.W. Green, R.B. Grossmam, C. Gutteridge, L. Jennens, S.C. Smith, P.L. Toogood \& A. Wood. 1995. Behavioral and neurophysiological responses of Spodoptera littoralis to azadirachtin and a range of synthetic analogues. Entomol. Exp. Appl. 77:69-80.

Simmonds, M.S.J., J.D. Manlove, W.M. Blaney \& B.P.S. Khambay. 2000. Effect of botanical insecticides on the foraging and feeding behaviour of the coccinelid predator Cryptolaemus montrouzieri. Phytoparasitica 28: 99107. 
Timmins, W.A. \& S.F. Reynolds. 1992. Azadirachtin inhibits secretion of trypsin in midgut of Manduca sexta caterpillars: reduced growth due to impaired protein digestion. Entomol. Exp Appl. 63: 47- 54.

Trisyono, A. \& M.E. Whalon. 2000. Toxicity of neem applied alone and in combination with Bacillus thuringiensis to Colorado potato beetle (Coleoptera: Chysomelidae). J. Econ. Entomol. 92: 1281-1288.
Trumm, P \& A. Dorn. 2000. Effects of azadirachtin on the regulation of midgut peristalsis by the stomatogastric nervous system in Locusta migratoria. Phytoparasitica 28: 7-26.

Turner, C.J., M.S. Tempesta, R.B. Taylor, M.G. Zagorski, J.C. Termini, D.R. Schroeder \& K. Nakanishi. 1987. An NMR spectroscopic study of azadirachtin and its trimethylether. Tetrahedron 43: 2789-2803. 